\title{
XXXIII. On painting
}

\section{Mr. E. Dayes}

To cite this article: Mr. E. Dayes (1802) XXXIII. On painting , Philosophical Magazine Series 1, 14:55, 218-228, DOI: $10.1080 / 14786440208676186$

To link to this article: http://dx.doi.org/10.1080/14786440208676186

$$
\text { 曲 Published online: } 18 \text { May } 2009 .
$$

Submit your article to this journal 전

LII Article views: 2

Q View related articles $\asymp$ 
cefs, the oxide, inflead of being abforbed, ought to flow from the furnace. This circumftance needs excite no uneafinefs; for the wind of the bellows, if well directed, will make the litharge flow along the gutter more abundantly than if there had been an abforption.

I have feen refiners in Germany, who, in conftructing their cupells of afhes, formed in the middle of it a fmall circular depreffion the diameter of which was proportioned to the quantity of the filver which they knew to be contained in the lead fubjected to the operation. By this excellent difpofition no grains of that valuable metal remain infulated from the cake; the whole runs into the central bafon, and forms a cake perfectly round. I would recommend this practice.

I am certain that the cupells here propofed, if carefully: and properly conftructed, will be attended with complete fuccefs; will be free from the inconveniences of thole of afhes, and at the fame time will be economical. I am defirous, for the benefit of metallurgy, that the method here pointed out may be put in practice: it will prove that we ought not to be too tenacious in adhering fervilely to antient ufages or to the common routine of workmen.

\section{On Painting. By Mr. E. Dayes, Painter *}

I

THINK it right again to repeat, that I have not obferved any order in the production of thefe Effays. They were written as the fubjects arofe in my mind, and the prefent paper thould be confidered rather as an introductory addrefs than otherwife. My motive in writing the prefent effay was to endeavour to remove the prejudice of thofe who confider the arts as a ufelefs ftudy, and their produce as things merely ornamental. But who, in a ftate of civil fociety, would be content with the ufefal or neceffary? Who is he whofe foul feeks not after perfection?

The motions of his fpirit are dull as night,

And his affeetions dark as Erebus :

Let no fuch man be trufted.

The fubject of the following effay had long engaged my attention; but I had dropped the idea of writing on it, in confequence of fome intelligent friends obferving it would be ufelefs, as no one could be fo ftupid as not to fee the ufefulnefs and influence of the arts on fociety. Experience,

* Communicated by the Author.

however, 
however, has taught the contrary; and I have been further ftrengthened in my refolution by oblerving, that the French National Inftitute, in their public fitting of April 5, had thought the inquiry of fufficient importance to offer it as 3 fubject for the premium of a gold medal *.

Francis-itreet, Bedford-fquare,

November 30,1302 .

Edward Dayes.

\section{Ess AY VII.}

On the Power and Ufefulne/s of Drawing.

I am perfuaded that to be a virtuolo (fo far as befits a gentleman) is a higher ftep towards becoming a man of virtue and good fenfe, than the being what in this age we call a tcholar.

Lord Shaftefbury.

IN this effay we have two objects in view: to thow the connection of drawing with painting; and to exhibit, in as clear a manner as we poffibly can, its ufefulnefs and influence on fociety.

But before we proceed it may be neceffary to obferve, that thofe who would queftion the utility of the arts, would be equally difpofed to queftion the utility of thefe effays that treat about them. Of their ufefulnefs we hope to be able to offer numberlefs proofs; but they rife fuperior to the merely ufeful. For that which is neceffary is neither ornamented nor elegant, becaufe neceffity implies poverty, while ornament implies abundance. Hence architecture, as an art, does not apply to mere houfe-building.

In defence of thefe effays, they are ferviceable by exhibiting the ufefulnefs of truth; and fo far they become an object to all thofe who with to be acquainted with the fubject handled, and to obtain a knowledge therein. But to thofe who never think or inquire, or concern themfelves with matters of fpeculation, or who take up with fpeculations without examining them, or read only to confirm themfelves in fuch as they have received, not any thing can become an object of concern, or any book be ufeful.

That man was not intended by nature for purpofes bafe and igrnoble, none will deny; and, if arguments were wanted, they might be drawn from that eternal inquiry after whatever is grand, dignified, or exalted; and, finally, after a ftate fuperior to our prefent terreftrial one. For it is not too much

* We cannot help thunking that Mr. Dayes has judged well in taking up this part of the fubject It is of great importance, and he has rendered an effenual fervice not only to the art atfelf, but to its liberal profefiors, by removing, as his arguments effectually do, ill-giounded prejudices againft its indifpenfable utility in civilized fociety; prejudices which could only criginate in, and be fottered by, ignurance and frupidity.-EDITOR. 
to affert, that we approach the Divinity in nothing fo much as in wifdom. Hence, as the arts are connected with wifdom, as men become carelefs of their culture, they become equally incapable of fulfilling the duties of focial beings. For knowledge is what humanizes mankind; reafon inclines them to mildnefs, but ignorance generates prejudice, which eradicates every tender feeling.

By drawing is meant the exact imitation of all the forms and manners which prefent themfelves to our fight; and in knowing how to give every thing its proper and correfponding character agreeably to the fubject confifts the excellence of what the artilt terms a good draftsman.

Drawing, as far as it is connected with mere imitation, is a mechanical operation, and may be acquired by a perfon of very moderate talents. So may a knowledge of bodies, properties, faets, events, and fables, by reading. But the powers of invention, the ojis poetica, which diftinguifhes the bard from the mere verfifier or journalit, the genius from the mere imitator and copyift, mutt be a gift from heaven befowed at the formation of the being. Neither this poetic energy nor the inventive powers of the artift can be taught in fchools or academies; but they both may be buried in ruft and inaction, if proper objects are not prefented to call them into motion. So the inventive powers of genius will be futile if unaccompanied by a fkill in drawing. Without this, the learning of the painter or fculptor cannot be thown to advantage: it is the fine qua non by which all the other accomplifhments are difplayed.

From what has been already ftated, the dependence of painting on drawing muft be obvious.

Genius has been compared to fire from flint, which can only be produced by collifion: if fo, fuccefs muft follow where nature directs and perfeverance attends. Activity is a neceffary ingredient to enable us to obtain a knowledge in art; and thould we find others out-ftep us, let us redouble our diligence, and comfort ourfelves with the recollection, that a late fpring produces the greateft plenty.

No one can poffibly judge of his powers from mere fpecuJation; the teft muft be applied before the value of the gold can be known. Nor will inactivity ever difcover how far our fortitude will enable us to overcome difficulties, our patience to bear difappointment, or our induftry enable us to range the wide field of art. For, were the arts of eafy attainment, they would be unworthy the notice of a great mind. This fhould induce us to increafe our exertions in proportion to our difappointments, remembering that to frive with 
with difficulties is noble, but to conquer is one of the higheft points of human felicity. It is in painting as in writing : where difficulties oocur, they arife from not clearly underftanding the fubject. Hence, to be able to reprefent an object juitly we mult underftand its fabrication; for it would be in vain to think of drawing the arch of a bridge correctly without knowing how it was keyed or put together, or even a bakket if we did not know how it was wove.

We thall now proceed to confider the power of drawing in a point of view merely ufeful.

How limited muft their ideas be who confider it as "the foundation of painting" only! We know it is fuch : for with out drawing it would be in vain to think of producing an effect; as mere colour without form muft remain a crude and undiftinguifhable mafs.

Drawing is not only an accomplifhment the moft elegant, agreeable, and ornamental, but, at the fame time that it is the foundation of painting, is of the utmoft utility to the fculptor, the civil and naval architect, the engraver, the engineer, the mathematician, and navigator. It alfo affifts the gardener, the cabinet-maker, the weaver, \&c. In fhort, there is fcarcely a branch of civil fociety that is not indebted to it, from the maker of the iron rails before our houfe to the tea-urn on our table. To it we are indebted for reprefentations of thofe elegant remains of antiquity that have contributed fo much to the advancement of our knowledge of fine form. Volumes of verbal defcription will never convey fo true an idea of a thing as the moft night fketch. Hence the fource of much of our knowledge in antiquity, of which language could convey no adequate idea.

To be able on the fpot to make a fketch of a fine building, beautiful profpect, or any curious production of nature or of art, is not only a very defirable and elegant accomplifhment, but in the higheft degree entertaining. To treafure up whatever may occur in our travels, either for future ufe or to illurtrate converfation, to reprefent the deeds of the great of former ages, to preferve the features of our moft valued friends, has made this art not only one of the higheft embellifhments of our nature, but the delight of all ages. The greateft writers have united to praile, and empires to encourage it. It has been in the higheft degree morally ufeful; and, where it has flourithed, conferred honour on the country. In fact, fociety could not fuftain a more fevere lofs than in being deprived of it; as many comforts, and all thofe elegancies that adorn the prefent itate of our being, mult depart with it. 
What has been the fate of thofe people whofe lawgivers forbid the practice of one part of the elegant arts? It appears they well knew, that where art refides, wifdom will ever be of the party; and dreaded the downfall of opinions built on a falfe bafe.

Wifdom is power, and power is what preferves a nation: hence thofe who thut the door againft knowledge are wilfully feeking their own deftruction: fuch is precifely the prefent ftate of the Turkifh empire.

\footnotetext{
Ye gods! what juftice rules the ball!

Freedom and arts together fall:

Fools grant whate'er ambition craves;

And men once ignorant are haves.
}

POPE.

What was the fate of Crete, that was fo renowned for her wifdom, valour, and laws? How did the fink under the tyranny and oppreffion of Rome? With their freedom departed their arts, their fciences, their valour, and their virtues. With the lofs of liberty we lofe all the ardour nature has furmithed us with to ftrengthen and fupport the flame of genius and the ardent glow of valour: without it we become deftitute of vigorous refolution, and fink below the natural virtue and dignity of our fpecies.

Drawing may be faid to poffefs a divine virtue in its creative power, and to be a perpetual miracle, as it preferves the images of diftant objects, and the likenefs of thofe we love.

Without rifking our lives on the boiferous ocean, we may enjoy at home, in a fmall book, reprefentations of the finelt productions of nature and art fituated in the remoteft regions of the world.

The wealth of a ftate, and the degree of civilization of its inhabitants, are fhown in the perfection of the elegant arts : no country ever flourifhed without them.

To fpeak of the power of drawing in a very limited point of view: without it we could not have maps and charts; without them we could not navigate; and without navigation we could not poffefs the advantages of commerce. Its application to hip-building muft be obvious, as every part is made to a fale. As a mere power of imitation, it unqueftionably fets man at the head of creation, no other animal having made even the attempt.

The arts have not only an influence on our manners but paffions, and, taken in a national point of view, are highly ufeful. The pictures reprefenting gallant actions or noble achievements roufe and ftimulate to acts of heroifm and 
public fpirit ; while thofe of a more elegant turn exhibit examples of graceful addrefs, and incline the mind to acts of beneficence and virtue.

However much we may lament that hiftorical painting is not fufficiently encouraged, yet we muft diffent from thofe who fupport the old but erroneous opinion, that our love of portrait-painting arifes from a national vanity. This ridiculous idea has been bandied aboit, both by foreigner and native, till many who take up with opinions without examining them have believed it true. We boldly aflert, on the contrary, that it is national virtue that gives it birth, and 2 defire the moft rational, that of preferving the images of thofe we love and delight in, conftantly before our eyes. It argues great national beneficence and goodnefs of heart. We may in fome meafure j:xdge of the difpofition of the mafter of a houfe from the number of portraits he poffeffes: they cannot be likeneffes of his enemies. Hence his choice muft be founded on love, and not, as the antients' was, on pride and vanity. The portrait-painter therefore becomes morally ufeful by increafing that focial tie that binds fociety together, in keeping before our eyes the images of departed worth or exifting merit. It is only thofe who neither love nor are beloved, that have no need of the portrail-painter.

Among the number of our own national advantages, and which fome may think fuperior to all others, we may obferve that the excellence of our artifts has turned the balance of trade in our favour. For whereas we formerly imported vaft quantities of prints, we now fupply all Europe, and import very few. Even for the decoration of our books we were formerly obliged to apply to ftrangers : but Heath has added a tafte to that department of art unknown to former engravers in the hiftorical line. Among the topographical publications, thofe prints that accompany the "Beauties of England and Wales" mult be highly interefting for tafte and beaty.

In the beginning of the latt century, the writers on the continent amufed themfelves in endeavouring to affign a caufe for the dulnefs of us iflanders in not having produced one hiftorical painter. Our nurthern latitude, being involved in fogs, was among the reafons affigned: but the caufe of fuch abfurd inquiries has cealed, and the mental capacity of Britons no one will now dare to queftion.

The confequence of our nation and the arts appear to have advanced together. The firft is evinced in our colonial poffeffions; and if we go back to the time of Henry VIII., we thall eafily difcover the ftate of commerce and the comfortlefs fituation of fociety compared with the prefent. Hollin- 
Thed obferves that chimneys were a novelty, as were pewter ornaments for the table. Straw formed the bed, and a good hard block of wood the pillow. Then was the dawn of the arts. Since which time they have been advancing, and are now, thank God! matured into a glorious mid-day, under the aufpices of his prefent majefty.

It is impoffible to fpeak of the arts without expreffing our gratitude towards their great patron; and were his name to flourith in no other way, that of George III. will be facred to pofterity with thofe of Leo, Julius, and all fuch as have a claim on eternity, as their protectors. His majefty has done for the arts what no monarch of this nation ever did before: lie has given, by his patronage, a turn to the national tafte highly beneficial to the profeffion, which the public are bound to fupport by a liberal and fair encouragement. With refpect to the mere act of buying, we are bound to confider his majefty in the light of a private gentleman, who regulates his expenditure according to his income: and we ought to thank God it is fo.

Holbein had not tafte enough to change the grotefque fathions of the court of Henry VIII. He brought about a revolution in architecture; but he introduced a mungrel ftyle, inferior to the Gothic of that period. Zuccaro was in England in the time of Elizabeth; and during that long reign we find little improvement in architecture, drefs, or in the general circle of elegancies. It was a court of intrigue and vanity. In the reign of James I. Van Somer and Cornelius Janfon paved the way for Van Dyck-an epoch of tafte: but this appears to have been confined to the court and a few noble collectors; and the troubles of Charles his fucceffor prevented his giving them a more general influence. His reign ftands high in the hiftory of architedure, from having produced Inigo Jones. Under Lely tafte funk into Indian gowns and flowing perukes; till fafhion became a monfter in the time of Kneller, and appeared in buckram coats, fquaretoed fhoes, and difproportioned head-dreffes in the ladies. This ftyle of drefs prevailed till within thefe few years, when goud fenfe and a more juft tafte broke through the buckram and whalebone, and produced the prefent eafy and elegant mode of attire; which may be faid to mark a point of national excellence. Reynolds contributed much to this change; his whole life was a ftruggle with the hydra fafhion, as his works evince.

The above ftatement will be found not to apply only to the article of drefs, but to extend to every department. Let us, for inftance, from the period of Henry VIII, examine 
thip-building, civil architesture, our furniture, plate, \&c. \&c., and we fhall find them to have nearly improved together, or to have fluctuated as the tafte for difin prevailed, till the patronage beftowed by his prefent majelty, by exciting a general love for the arts, improved the national talte to its prefent great and highly refpectable ftate.

Before we difmifs the prefent effay we thall endeavour to point out fome of the advantages that refult from the practice of drawing, to thofe who do not make a profeffion of it. Many muft be obvious from the former part of this paper. To every gentleman who travels, it is abfolutely neceffary; for, independently of its teaching him to fee accurately, the curious and ever-reftlets eye of the artift comprehends more at one view than the common obferver will notice in an age. The volume of nature is laid open to him; his attention is directed to the vaft and minute; men and manners are not concealed from his view, and his imagination clings to perfection with inefiable delight.

It is not too much to fay, that drawing opens the mind more than years devoted to the acquiring of languages, or the mere learning of words: it teaches to think. The artift is a true logician : not content with producing effects, he is ever inquiring after caufes founded on a vifible demonftration, to exhibit them in his works.

We mult not rank it among the leaft of the advantages refulting from the practice of the arts, that it enures the reflecting mind to the moft enticing fort of logic. The practice of reafoning upon objects in themfelves agreeable tends to produce fuch a habit, and habit ftrengthens the reafoning faculties. Befides, while the mind is engaged in obtaining knowledgre, we efcape the infipidity and indifference connected with the tedioufuefs of inactivity. Hope attends labour; a blefing unkuown to thofe who live lazily on the toil of others. The fenfualift imagines he enjoys the world becaufe he eats and drinks, and runs about upon it; but to enjoy it truly, is to be fenfibie of its greatnefs and beauty.

Independently of keeping the mind employed, the arts contribute to harmonize the temper; and the power of drawing brings with it fo much mental enjoyment, that youth, in order to be nccupied, is not tempted to precipitate into the ruinous and deftructive vices of gaming and drinking. It defends us in the meridian of life from the wild fchemes of ambition, and in old age it becomes a fure thield againt avarice. Shenftone obferves, "Wherever there is a want of tafte, we generally obferve a love of money and emming."
VOL. XIV. No. 55 . $p$ 
The influence it has on our moral conduct is, perhaps, one of the greateft recommendations for the ftudy of the arts. No one can meditate on the order obfervable in nature, and not reduce his conduct to a fimilar ftandard of regularity. To have a juft relifh for what is elegant and proper in painting, fculpture, or architedure, mult be a fine preparation for true notions relative to character and behaviour. Should fuch a one be overpowered by paffion, or fwerve from his duty, we need not fear but he will return on the firt reflection, and with a redoubled refolution not to err a-fecond time: for he camnot but obferve, that the well-being of nature, as well as of the individual, depends on regularity and order; and that a diliregard of the focial virtues will ever be accompanied with thame and remorfe. Paffon is a whirlwind, that thakes the human frame, as the convulfions of an carthquake diforder that of nature.

Every Briton that travels fhould propofe to himfelf pleafure and advantage, and his inquiry thould enable him to add to the national ftock of knowledge; for it cannot be faid that he travels to enjuy the advantage of a better government, or becaufe other nations have a greater commerce. Hence, then, it muft be for arts and learning. And how is he to become acquainted with the former without a knowledge in painting, fculpture, and architecture, any more than he could with the latter, without a knowledge in the languages of the countries he may have occafion to pafs through ? Lord Bacon $f_{d y}$ : "Travel, in the younger fort, is a part of education; in the elder, a part of experience. He that travelleth into a country before he hath fome entrance into the language, goeth to fchool and not to travel." The fame may be faid of thofe who travel before they have obtained a knowledge in the polite arts. How many noble works of architecture did lord Burlington bequeath to his country! They remain monuments of national tafte, highly honourable to his memory. Let us be permitted to mention the honour the arts at prefent derive from the malterly productions of the earl of Aylesford, fir. G. Beaumont, fir R. Hoare, W. Scope, efq. of Caltle-comb ; captain Lewis, of the royal navy; capt. Mordaunt, and many others, whofe works will ever rank anong the firft productions of the peneil. Lord Warwick is faid to poffefs the true poetic pirit for compofing heroic landicape. While we are recommending to gentlemen to learn to draw, it mult not be underftood that we wifh to deprive the ladies of the pleafure and advantage that mult refult from their practifing an art that ftands, perhaps, before all others for improving 
improving our tafte, particularly in fuch things as are connected with decoration.

Though we recommend learning to draw thus generally, we muft fay it requires the utmoft caution in the choice of a mafter; for, thould his abilities be confined, or his tafte depraved, there is great danger of the poifon being conveyed to the pupil: and if, in the end, his better underftanding rife fuperior to the evil, he will, unfortunately, have much to unlearn. Above all, if he be arrived at an age to difcriminate, objects worthy attention thould be fet as examples of imitation; he fhould not be amufed and his time wafted with gew-gaws and trafh beneath the dignity and attention of rutional beings.

Every one is acquainted with the progrefs of what may be termed common or fchool education. The mafters begin teaching the letters, and then proceed to fyllables, which are joined into fentences: but the ultimate end is, compofing themes to call forth the power of invention, and convey a more exquifite idea of the language. Exactly fo hould be the progrefs in teaching drawing. If the knowledge to be obtained be the human figure, we begin with parts ; as eyes, nofes, heads, hands, \&c., which is the A B C. This, of courfe, leads to the whole figure, which may be compared to fpelling; that naturally conducts to the round, or drawing from plaifter calts; then from the life; and ultimately to compofition. Should landfcape be the purfuit, the progrefs is precifely the fame. We begin with parts or fingle objects; as trees, bridges, cottages, caftles, \&c. Here again is the alphabet. This we too quit to copy wholes, or a combination of objects; and in the end we apply to nature, which fets us free from our mafter. Then we mut improve by our own activity; and, like the bee, cull the boney from every flower. As much of our fuccels depends on the abilities of the nafter, the greateft care hould be obferved in the choice. He is but as a crutch to the lame; but we ought to make ourfelves fure it is found, and withont flaw or thake; that is, as far as our judgment will permit, or the opinion o friends direet.

He who afpires to a knowledge in the fine arts can only hope to fucceed by turning his attention to the fenfitive part of nature, particularly by an inquiry after fuch objects as are naturally agrecable, or the contrary: allo fuch as are grand or mean, proper or improper. This is the only foundation of a juft and rational tafte, and, like morals, may be cultivated to a high degree of refinement. The fine arts, where the feelings only are concerned, will pleafe, from their no- 
velty, in the prime of life; but the delight will ceafe in a more adranced period, when the fervour of the imagination goes off: On the contrary, where we are governed by juft principles and a thorough knowledge, they will afford fcope for fancy as well as judgment, they will grow into a favourite entertainment, and their vigour will prevail as ftrong in the evening as in the morning of life. This only can make the arts truly delightful. It is not a few technical phrafes, picked up from profeflional men, which may enable one to babble like a parrot, that can at any time pleafe or be pleafing. Science is a coy lady, and will not grant her favours without being long courted. But, thould we afpire to no higher character than that of the mere critic, a fmall ftock of information will fuffice; and practice will increafe confidence where there is nothing to lofe. Criticifin is a lady of eafy accefs : the want of meaning fhe fupplics with words; and the want of knowledge is recompenfed with cunning. She flatters all; and thofe whom nature has made weak, or idlenefs keeps ignorant, may feed their vanity at her fhrine.

XXXIV. On the Diffirences wbich exift between the Heads of the Mammotb and Eleplant. By. REMBRANDT PEALE, Ejq.*

$\mathrm{T}$

HE drawings which accompany this (fee Plate V.) are intended to explain the differences between the head of the mammoth and that of the elephant. The teeth form the moft ftriking character : thofe of the elephant are exclufively graminivorous, and confequently diftinguifhed from thofe of the mammoth, which were intended for animal food of fome kind, and not improbably thell-fifh, on the fuppofition that the animal was amphibious $\uparrow$ : and this may account for the peculiar form and pofition of the tufks. On examining the head of the elephant, it will appear that the fockets for the tuks at $A$ are fituated, with refpect to the condyle of the neck at $B$, nearly in an angle of 45 degrees; to that the tulks, which have but little curve, are direeted downwards and forwards, and may be with eafe employed oftenfively and defenfively. On the other hand, it will be obferved that in the mammoth the focket $A$ is nearly on a horizontal line with the condyle B; and therefore the tufks, which are femicircular, could never have been elevaled in the air, pointing

* Communicated by the Author.

$\uparrow$ Sec the former number, p. 162-169 of the prefent volume. 